\title{
Plasminogen activators in synovial fluid and plasma from patients with arthritis
}

\section{Gaubius Laboratory} IVVO-TNO,

University Hospital Leiden, The Netherlands E J P Brommer

G Dooijewaard

Department of Rheumatology, University Hospital, Leiden, The Netherlands

B A C Dijkmans

F C Breedveld

Correspondence to: Dr E J P Brommer, University Hospital Leiden, Department of Rheumatology, PO Box 9600, 2300 RC Leiden, The Netherlands.

Accepted for publication 17 January 1992

\begin{abstract}
The activity of plasminogen activators and inhibitors in the synovial fluid and plasma of patients with various forms of chronic arthritis was characterised. Tissue-type plasminogen activator antigen (t-PA:Ag), urokinase-type plasminogen activator antigen (u-PA:Ag), the proenzyme single chain u-PA (scu-PA), and plasminogen activator inhibitor (PAI) were measured in the synovial fluid and plasma of 22 patients with seropositive rheumatoid arthritis (RA), 13 with seronegative RA, and 23 patients with various forms of arthritis. In all patient groups the levels of t-PA:Ag in synovial fluid were lower and the levels of $u$ PA:Ag and PAI higher than plasma levels. Synovial fluid u-PA was more activated than plasma u-PA. Comparison of the patient groups showed that the largest differences between fibrinolytic parameters in synovial fluid and plasma were present in patients with seropositive RA followed by patients with seronegative RA and patients with various forms of arthritis. This order paralleled the functional and radiological scores of joint destruction in the patient groups studied. The results of this study indicate that suppression of t-PA production and enhancement of u-PA synthesis and activation in arthritic joints are associated with the clinical severity of arthritis.
\end{abstract}

(Ann Rheum Dis 1992; 51: 965-968)

Removal of fibrin may be crucial for the preservation of the function of arthritic joints. Fibrin degradation products have been demonstrated in arthritic synovial fluid, which suggests that fibrinolysis occurs in the joint cavity. ${ }^{1}$ Indeed, the essential components of the fibrinolytic system are available in arthritic effusions. ${ }^{2-7}$ Tissue-type plasminogen activator (t-PA) is produced in an active form and is rapidly neutralised by plasminogen activator inhibitor (PAI). In contrast, urokinase-type plasminogen activator ( $u-P A)$ is released in a latent form, single chain u-PA (scu-PA), which can be activated to two chain u-PA by trace amounts of plasmin. ${ }^{89}$ The two forms of u-PA are detectable as $\mathrm{u}-\mathrm{PA}$ antigen ( $\mathrm{u}-\mathrm{PA}: \mathbf{A g}$ ) even when the activated form is bound to inhibitors. ${ }^{10}$ The actual generation of plasmin, the proteolytic enzyme responsible for the breakdown of fibrin, has been witnessed in synovial fluid of patients with arthritis by the presence of plasminantiplasmin complexes. 5

There is ample evidence that proteolytic enzymes play a part in the pathogenesis of joint destruction in patients with arthritis. Enzymes of the fibrinolytic system may contribute to the degradation of components of connective tissue. Plasmin has the capacity to degrade proteoglycans $^{11-13}$ and to activate procollagenase to collagenase. ${ }^{14}$ Changes in the concentration of fibrinolytic enzymes or their inhibitors may therefore be of significance for the pathogenesis of joint destruction in chronic arthritis. In this study we characterised the plasminogen activators in patients with several types of arthritis: t-PA:Ag, u-PA:Ag, and the concentration of PAI were measured in synovial fluid and plasma. The data were compared with those of plasma obtained from healthy subjects.

\section{Patients and methods}

Synovial fluid and blood samples were collected from 58 consecutive patients attending the outpatient clinic of the department of rheumatology with arthritis of the knee joint for which aspiration of synovial fluid was considered necessary. Thirty five patients had rheumatoid arthritis (RA) according to the American Rheumatism Association criteria. ${ }^{15}$ Twenty two of these patients were positive and 13 negative for IgM rheumatoid factor as measured by an enzyme linked immunosorbent assay (ELISA). ${ }^{16}$ The remaining group of 23 patients, designated as having various forms of arthritis, consisted of nine patients with reactive arthritis, four with ankylosing spondylitis, seven with psoriatic arthritis, and three with oligoarticular arthritis. All patients with arthritis were receiving nonsteroidal anti-inflammatory drugs. In addition, four of the patients with RA were treated with gold, three with hydroxychloroquine, three with D-penicillamine, three with azathioprine, four with salazosulphapyridine, and four with methotrexate. No patient had received an intraarticular injection within four weeks before the aspiration of synovial fluid. Plasma samples from 17 apparently healthy subjects were also analysed. The functional ability of the patients with arthritis was measured by the Steinbrocker classification criteria. ${ }^{17}$ Radiographs of the knees were assessed according to the criteria of Kellgren. ${ }^{18}$ Erosions were scored on a five point scale, where $0=$ no abnormalities, $1=$ doubtful abnormalities, $2=$ mild but definite abnormalities, $3=$ moderate erosions, and $4=$ severe destructive lesions or ankylosis, or both. The percentage of joints affected was defined as the number of joints with erosions with a score of 2 , 3 , or 4 , or joint space narrowing, or both.

Nine parts of synovial fluid were collected in one part of $0.11 \mathrm{~mol} / 1$ sodium citrate. From all patients blood was obtained on the day of joint puncture. Plasma was prepared by centrifugation 
of cooled citrated blood (9:1). Plasma and synovial fluid were stored at $-80^{\circ} \mathrm{C}$ until analysis.

Plasma and synovial fluid u-PA:Ag and scuPA were determined using a combination of an ELISA and a biological immunoassay. ${ }^{10}$ The lower detection limit in our material was $0 \cdot 1$, 0.2 , or $0.4 \mathrm{ng} / \mathrm{ml}$, according to the dilution used, which depended on the available amount of plasma or synovial fluid (either 50, 25, or $12 \cdot 5 \mu$, respectively).

Plasma and SF t-PA:Ag was assayed by an enzyme immunoassay, using antibodies to t-PA (Immulyse, Biopool, Umeå, Sweden). PAI activity was measured by titration of diluted plasma with $\mathrm{t}-\mathrm{PA}^{19}$; results of PAI activity are expressed as a percentage of a standard plasma pool.

\section{STATISTICAL ANALYSIS}

Means and standard deviations were calculated after eliminating aberrant values according to the slippage test. ${ }^{21}$ Differences between

Table 1 Demographic and clinical data of the patients studied

\begin{tabular}{|c|c|c|c|}
\hline & \multicolumn{3}{|c|}{ Patient groups } \\
\hline & $\begin{array}{l}\text { Seropositive } \\
\text { rheumatoid } \\
\text { arthritis } \\
(n=22)\end{array}$ & $\begin{array}{l}\text { Seronegative } \\
\text { rheumatoid } \\
\text { arthritis } \\
(n=13)\end{array}$ & $\begin{array}{l}\text { Diverse } \\
\text { forms of } \\
\text { arthritis } \\
(n=23)\end{array}$ \\
\hline $\begin{array}{l}\text { Men/women } \\
\text { Mean (SD) age (years) } \\
\text { Mean (SD) duration of arthritis (years) } \\
\text { Mean (SD) Steinbrocker score } \\
\text { Radiological abnormalities (\%) } \\
\text { Mean (SD) joint erosion score } \\
\text { Mean (SD) erythrocyte sedimentation rate }\end{array}$ & $\begin{array}{l}15 / 7 \\
57(18) \\
13(6) \\
1 \cdot 96(0 \cdot 86) \\
81 \\
3 \cdot 1(0 \cdot 9)\end{array}$ & $\begin{array}{l}8 / 5 \\
53(16) \\
12(6) \\
1 \cdot 32(0 \cdot 61) \\
39^{* * *} \\
2 \cdot 0(0 \cdot 6)^{*}\end{array}$ & $\begin{array}{l}13 / 10 \\
49(21) \\
4(3)^{* * * *} \\
1 \cdot 14(0 \cdot 51) \\
26^{* *} \\
1 \cdot 6(0 \cdot 7)^{* *}\end{array}$ \\
\hline Mean (SD) platelet count $\left(\times 10^{9} / 1\right)$ & $\begin{array}{l}60(32) \\
371(144)\end{array}$ & $\begin{array}{l}36(17)^{*} \\
287(62)\end{array}$ & $\begin{array}{l}31(28)^{* *} \\
292(105)\end{array}$ \\
\hline
\end{tabular}

*Comparison with patients with seropositive rheumatoid arthritis; $\mathrm{p}<0.01$.

** Comparison with patients with seropositive rheumatoid arthritis; $\mathrm{p}<0.001$.

${ }_{* * *}$ Comparison with patients with seropositive rheumatoid arthritis and seronegative rheumatoid arthritis; $p<0.001$.

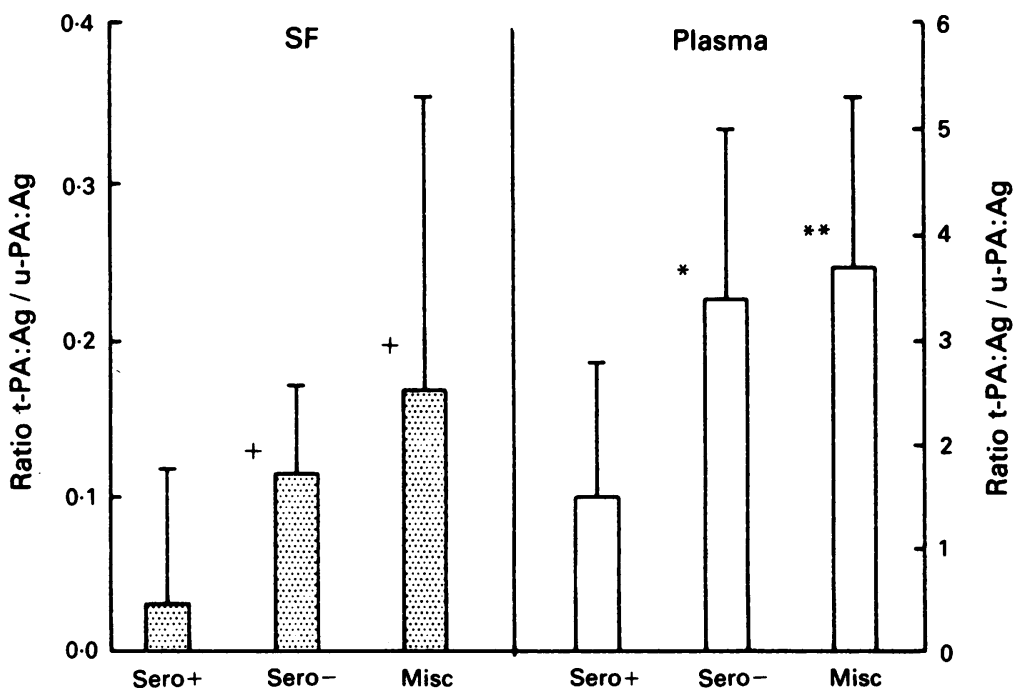

Figure 1 Ratios of tissue-type plasminogen activator antigen (t-PA:Ag) to urokinase-type Figure 1 Ratios of tissue-type plasminogen activator antigen (t-PA:Ag) to urokinase-type
plasminogen activator antigen ( $u-P A: A g)$ in synovial fluid $(S F)$ and plasma of patients with seropositive $R A$ (sero+), seronegative $R A$ (sero-), and miscellaneous forms of arthritis (misc). The ratios in synovial fluid were not normally distributed and medians (grey bars) and 75 centiles (vertical lines) are given; the ratios in plasma are expressed as mean (SD). The differences with values found in seropositive $R A$ are given: ' $p<0.02 ;{ }^{*} p<0.001$; ${ }_{* *} p<0.0005$ (Mann-Whitney). means were evaluated with Student's $t$ test after omitting the aberrant values. Ratios were compared with the Mann-Whitney test.

\section{Results}

PATIENTS

The patients with arthritis studied were divided into three groups: seropositive RA, seronegative RA, and various forms of arthritis. The groups did not differ with respect to age and male to female ratio. The disease duration in the group with various forms of arthritis was shorter on average compared with the groups of patients with RA. Table 1 shows that patients with seropositive RA had higher scores for functional disability, more radiological abnormalities, more erosions of the aspirated knee joint, and a higher erythrocyte sedimentation rate and platelet count compared with patients with seronegative RA and patients with various forms of arthritis. These clinical parameters were less abnormal in patients with various forms of arthritis compared with patients with seronegative RA but the differences were not statistically significant.

PLASMA t-PA:Ag, u-PA:Ag, AND PAI

Table 2 shows that the t-PA:Ag concentration in the plasma of patients with seropositive RA was significantly lower than in the plasma of patients with seronegative $R A$, various forms of arthritis, or plasma from healthy control subjects $(\mathbf{p}<0.01)$. In contrast, the u-PA:Ag concentration in plasma of patients with seropositive RA was significantly higher compared with patients in the other groups or healthy controls $(p<0 \cdot 005)$. Figure 1 gives the ratios of t-PA:Ag and $u$ $\mathrm{PA}: \mathrm{Ag}$ in plasma of the patient groups and healthy controls. This ratio was lower in the patients with seropositive RA than in the other patient groups.

The PAI concentrations in plasma did not differ between the patient groups but all were significantly lower when compared with the concentrations in healthy controls $(p<0.02$; table 2).

SYNOVIAL FLUID t-PA:Ag, u-PA:Ag, AND PAI The concentration of $\mathrm{t}-\mathrm{PA}: \mathrm{Ag}$ in synovial fluid of patients with seropositive $R A$ was significantly lower than in patients with seronegative RA or other forms of arthritis $(p<0.005)$. Concentrations of t-PA:Ag in synovial fluid of all patient groups were significantly lower than the plasma levels $(p<0.005)($ table 3$)$. The concentrations of u-PA in synovial fluid of all patient groups were significantly higher $(p<0.001)$ than in plasma but these concentrations did not differ significantly between the patient groups. The ratios of t-PA:Ag and u-PA:Ag in synovial fluid of the patient groups studied are given in fig 1. The differences between all groups were statistically significant. As a result of the differences in t-PA:Ag and u-PA:Ag in synovial fluid and plasma the t-PA:Ag to u-PA:Ag ratios in these compartments differed by at least a factor of 10 (fig 1). 
Table 2 Mean $(S D)$ plasma concentrations of plaminogen activators and inhibitor obtained from patients with different forms of arthritis and healthy control subjects

\begin{tabular}{|c|c|c|c|c|}
\hline \multirow{2}{*}{$\begin{array}{l}\text { Parameter } \\
\text { measured }\end{array}$} & \multicolumn{3}{|l|}{ Patients } & \multirow{2}{*}{$\begin{array}{l}\begin{array}{l}\text { Healthy } \\
\text { control } \\
\text { subjects }\end{array} \\
(n=17)\end{array}$} \\
\hline & $\begin{array}{l}\text { Seropositive } \\
\text { rheumatoid } \\
\text { arthritis } \\
(n=22)\end{array}$ & $\begin{array}{l}\text { Seromegative } \\
\text { rheumatoid } \\
\text { arthritis } \\
(n=13)\end{array}$ & $\begin{array}{l}\text { Diverse } \\
\text { forms of } \\
\text { arthritis } \\
(n=23)\end{array}$ & \\
\hline $\begin{array}{l}\text { t-PA:Ag (ng/ml) } \\
\text { u-PA:Ag (ng/ml) } \\
\text { PAIt } \\
\text { scu-PA (ng/ml) }\end{array}$ & $\begin{array}{l}6.7(6 \cdot 2) \\
4.8(1.6) \\
59(28) \\
1.6(0 \cdot 4)\end{array}$ & $\begin{array}{l}11 \cdot 1(5 \cdot 0) \\
3 \cdot 2(0 \cdot 7) \\
64(37) \\
1 \cdot 7(0 \cdot 4)\end{array}$ & $\begin{array}{l}12 \cdot 8(5 \cdot 8) \\
3 \cdot 5(0 \cdot 8) \\
75(29) \\
1 \cdot 9(0 \cdot 5)\end{array}$ & $\begin{array}{l}10 \cdot 9(4 \cdot 6) \\
3 \cdot 5(1 \cdot 1) \\
122(80) \\
2 \cdot 1(0 \cdot 3)\end{array}$ \\
\hline
\end{tabular}

*(t-PA:Ag) Tissue-type plasminogen activator antigen; (u-PA:Ag) urokinase-type plasminogen activator antigen; (PAI) plasminogen activator inhibitor; (scu-PA) single chain urokinase plasminogen activator.

†Percentage of a standard plasma pool.

Table 3 Mean (SD) synovial fluid concentrations of plaminogen activators and inhibitor obtained from patients with different forms of arthritis

\begin{tabular}{llll}
\hline $\begin{array}{l}\text { Parameter } \\
\text { measured }\end{array}$ & Patients & & \\
\cline { 2 - 4 } & $\begin{array}{l}\text { Seropositive } \\
\text { rheumatoid } \\
\text { arthritis } \\
(n=22)\end{array}$ & $\begin{array}{l}\text { Seronegative } \\
\text { rheumatoid } \\
\text { arthritis } \\
(n=13)\end{array}$ & $\begin{array}{l}\text { Diverse } \\
\text { forms of } \\
\text { arthritis } \\
(n=23)\end{array}$ \\
\hline t-PA:Ag $(\mathrm{ng} / \mathrm{ml})$ & $1 \cdot 5(1 \cdot 5)$ & $4 \cdot 1(4 \cdot 0)$ & $3 \cdot 2(2 \cdot 3)$ \\
u-PA:Ag $(\mathrm{ng} / \mathrm{ml})$ & $23 \cdot 8(14 \cdot 7)$ & $22 \cdot 1(8 \cdot 4)$ & $19 \cdot 9(14 \cdot 9)$ \\
PAI† & $272(166)$ & $232(114)$ & $186(135)$ \\
scu-PA $(\mathrm{ng} / \mathrm{ml})$ & $1.9(1 \cdot 6)$ & $5 \cdot 8(2 \cdot 2)$ & $4 \cdot 0(1.6)$
\end{tabular}

*(t-PA:Ag) Tissue-type plasminogen activator antigen; (u-PA:Ag) urokinase-type plasminogen activator antigen; (PAI) plasminogen activator inhibitor; (scu-PA) single chain urokinase plasminogen activator.

†Percentage of a standard plasma pool.

As for $\mathrm{u}-\mathrm{PA}: \mathrm{Ag}$, the PAI concentrations in synovial fluid of all patient groups were significantly higher than in plasma $(p<0.005)$, whereas the differences between the patient groups did not differ significantly (table 3 ).

\section{ACTIVATION OF U-PA IN PLASMA AND SYNOVIAL FLUID}

Not only total u-PA:Ag, but also scu-PA levels were significantly higher in synovial fluid than in plasma in all groups of patients with arthritis $(\mathrm{p}<0.001$; tables 2 and 3$)$. When scu-PA is activated to the active enzyme, the ratio of scuPA to total u-PA:Ag in plasma or in synovial fluid will decrease. Consequently, this ratio can be regarded as a measure of the activation of $u$ PA. For all groups of patients with arthritis the mean ratio between scu-PA and u-PA:Ag was

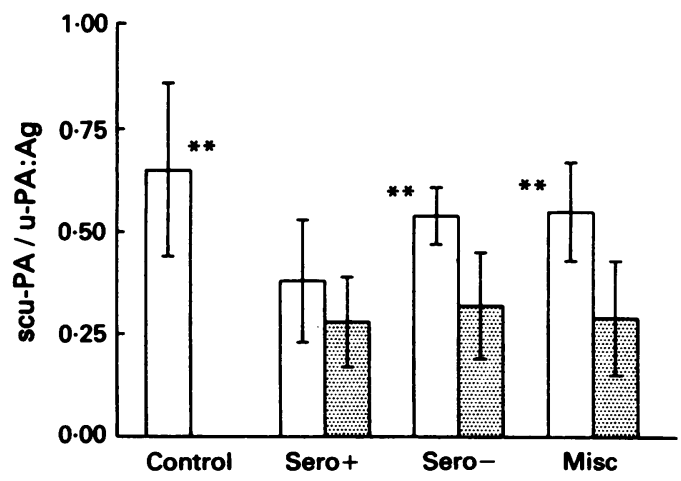

Figure 2 Ratios of single chain u-PA (scu-PA) to urokinase-type plasminogen activator antigen (u-PA:Ag) in plasma (open bars) and symovial fluid (grey bars) of patients with seropositive $R A$ (sero+), seronegative $R A$ (sero-), and miscellaneous forms of arthritis (misc) and healthy controls. Differences with seropositive $R A$ are indicated: ${ }^{* *} p<0.001$ (Mann-Whitney). lower in synovial fluid than in plasma-that is, the degree of activation of $\mathrm{u}-\mathrm{PA}$ was higher ( $<<0.025$; fig 2). The degree of activation in plasma was significantly higher in patients with seropositive RA than in the other groups of patients with arthritis and higher than in healthy controls. In synovial fluid, differences between patients with seropositive RA and those with other forms of arthritis did not reach statistical significance.

\section{Discussion}

The results of this study show considerable differences between synovial fluid and plasma concentrations of the components of the fibrinolytic system in patients with arthritis. In synovial fluid the t-PA:Ag concentration was lower whereas the u-PA:Ag and PAI concentrations were higher than plasma levels. Consequently, the ratio of $\mathrm{t}-\mathrm{PA}: \mathrm{Ag}$ to $\mathrm{u}-\mathrm{PA}: \mathrm{Ag}$ was on average ten times lower in synovial fluid than in plasma. Furthermore, in all patient groups the mean ratio between scu-PA and u-PA:Ag was significantly lower in synovial fluid, which indicates a higher degree of $\mathrm{u}-\mathrm{PA}$ activation in synovial fluid than in plasma. Comparison of the patient groups showed that the largest fibrinolytic changes in synovial fluid were present in patients with seropositive RA followed by patients with seronegative RA and various forms of arthritis. Within the latter group, no significant differences in the concentration of synovial fluid fibrinolytic parameters were found between patients with different forms of arthritis (data not shown).

The presence of $u-P A$ as the main plasminogen activator in synovial fluid of patients with arthritis confirms earlier observations. ${ }^{47}$ The u-PA in joint fluid may originate from several sources. Cultured synovial fibroblasts, as well as chondrocytes, macrophages and endothelial cells have been shown to produce u-PA. ${ }^{22-26}$ The effect of increased u-PA:Ag concentrations and increased u-PA activation in the arthritic joint is unclear. Fibrin is persistently present in synovial fluid, which suggests that $\mathrm{u}-\mathrm{PA}$ is prevented from the complete activation of plasminogen and from dissolving fibrin. If the complementary and synergistic activation of fibrin bound plasminogen by u-PA and t-PA, as proposed by Gurewich, ${ }^{27}$ requires a certain balance between t-PA and u-PA, the disturbance of the normal ratio could reduce the fibrinolytic potential. The high levels of PAI found in the synovial fluid of arthritic joints may also contribute to the incomplete effect of the plasminogen activators on fibrin dissolution as fibrinolytic activity is greatly influenced by PAI activity. ${ }^{28} 29$ Differences in the synovial fluid fibrinolytic parameters between patient groups with various forms of inflammatory arthritis have not previously been reported. The ratio $t-P A: A g / u-$ PA:Ag and the activation of u-PA in the group of patients with arthritis paralleled the functional and radiological scores of joint destruction. This relation may be secondary to differences in the production of cytokines. It has been shown that interleukin 1 and tumour necrosis factor stimulate the production of u-PA:Ag and PAI 
and inhibit the output of t-PA in cultures of endothelial $^{26}$ or mesothelial ${ }^{30}$ cells. Interleukin 1 and tumour necrosis factor were also shown to induce a decrease in the ratio of scu-PA to uPA:Ag. ${ }^{26}$ Interleukin 1 and tumour necrosis factor are actively produced in the chronic inflamed joint and are known to initiate a series of destructive processes when injected into joints. ${ }^{31-33}$ Therefore the results of this study suggest that changes in the local concentration of fibrinolytic enzymes may be one of the pathways along which cytokines induce joint destruction.

A comparison of the fibrinolytic changes in plasma of the patient groups investigated showed that the t-PA:Ag to u-PA:Ag ratio and the scu-PA to u-PA:Ag ratio of patients with seropositive RA was significantly reduced compared with the other groups of patients with arthritis. Similar changes have been reported in patients with sepsis. ${ }^{34}$ For arthritis, it is unlikely that these changes are due to an overflow of $\mathrm{u}-\mathrm{PA}$ from the joints into the circulation, because high plasma levels of u-PA do not parallel synovial fluid levels. The change may reflect the systemic nature of the inflammatory process in patients with seropositive RA.

Synovial fluid u-PA activity can be reduced by the administration of inhibitors. Administration of u-PA inhibitors to experimental animal models of arthritis suggests that such treatment may protect against joint destruction. ${ }^{35}$ Preliminary studies in patients with RA and osteoarthritis have shown that intra-articular injections of $\mathrm{u}-\mathrm{PA}$ inhibitors lead to a significant reduction in local u-PA activity. 636

The results of this study support the hypothesis that changes in the concentration of plasminogen activators are of pathophysiological significance for joint destruction in arthritis. It remains to be established whether normalisation of the t-PA to u-PA ratio and the degree of activation of $\mathrm{u}-\mathrm{PA}$ can reduce the severity of joint lesions in patients with chronic arthritis.

1 Jespersen J, Brommer E J P, Haverkate F, Nieuwenhuizen $W$. Degradation products of fibrin and of fibrinogen in synovial fluid and in plasma of patients with rheumatoid arthritis. Fibrinolysis 1989; 3: 183-6.

2 Barnhart M I, Riddle J M, Bluhm G B, Quintana C. Fibrin promotion and lysis in arthritic joints. Ann Rheum Dis 1967; 26: 206-8.

3 Belch J J F, McArdle B, Mashok R, et al. Decreased plasma fibrinolysis in patients with rheumatoid arthritis. Ann Rheum Dis 1984; 43: 774-7.

4 Mochan E, Uhl J. Elevations in synovial fluid plasminogen activator in patients with rheumatoid arthritis. $\mathcal{f}$ Rheumato 1984; 11: 123-8.

5 Inman R D, Harpel P C. $\alpha_{2}$-Plasmin inhibitor-plasmin complexes in synovial fluid. $\mathcal{f}$ Rheumatol 1986; 13: 535-7.

6 Kikuchi H, Tanaka S, Matsuo O. Plasminogen activator in synovial fluid from patients with rheumatoid arthritis. $\mathcal{F}$ Synovial fluid from patients

7 Lindenhayn K, Heilmann H H, Regling G, Haupt R. Die Plasminogen-activator-Aktivität der synovialflüssigkeit als Indikator für Aktievierungsphänomene bei degenerativen Gelenkerkrankungen. $Z$ Rheumatol 1989; 48: 246-53.

8 Bernik M B, Oller E P. Regulation of fibrinolysis through activation and inhibition of activation of a plasminogen proactivator (preurokinase). Thromb Haemost 1977; 38: 136.
9 Gurewich V, Pannell R. Inactivation of single-chain urokinase (prourokinase) by thrombin and thrombin-like enzymes: (prourokinase) by thrombin and thrombin-like enzymes: relevance of the finding to the interpretation
binding experiments. Blood 1987; 69: 769-72.

10 Binnema D, Van Iersel J J L, Dooijewaard G. Quantitation of urokinase antigen in plasma and culture media by use of an ELISA. Thromb Res 1986; 43: 569-77.

11 Lack C H, Rogers H J. Action of plasmin on cartilage. Nature 1958; 182: 948-9.

12 Mochan E, Keler T. Plasmin degradation of cartilage proteoglycan. Biochim Biophys Acta 1984; 800: 312-5.

13 Collier S, Ghosh P. The role of plasminogen in interleukin-1 mediated cartilage degradation. $\mathcal{F}$ Rheumatol 1988; 15: $1129-37$.

14 Werb Z, Mainardi C L, Vater C A, Harris E D. Endogenous activation of latent collagenase by rheumatoid synovial cells. $N$ Engl f Med 1977; 296: 1017-23.

15 Arnett F C, Edworthy S M, Bloch D A, et al. The American Rheumatism Association 1987 revised criteria for the classification of rheumatoid arthritis. Arthritis Rheum 1988; 31: $315-28$.

16 Otten H G, Daha M R, de Rooy H H, Breedveld F C. Quantitative detection of class-specific rheumatoid factors using mouse monoclonal antibodies and the biotin/streptavidin enhancement system. Br $\mathcal{J}$ Rheumatol 1989; 28: $310-6$.

17 Steinbrocker O, Traeger C H, Batterman R C. Therapeutic criteria in rheumatoid arthritus. FAMA 1949; 140: 659-62.

18 Atlas of standard radiographs of arthritis. In: Kellgren J H ed. The epidemiology of chronic rheumatism. Vol 2. Oxford: Blackwell, 1963.

19 Verheijen J H, Chang G T G, Kluft C. Evidence for the occurrence of a fast-acting inhibitor of tissue-type plasminogen activator in human plasma. Thromb Haemost 1984, 51: $392-5$.

20 Doornbos $\mathbf{R}$, Prins $\mathbf{H}$ J. On slippage tests. Indagationes Mathematicae 1958; 20: 38-55.

21 Doornbos $\mathrm{R}$, Prins $\mathrm{H}$ J. On slippage tests. Indagationes Mathematicae 1958; 20: 438-47.

22 Medcalf R L, Hamilton J A. Human synovial fibroblasts produce urokinase-type plasminogen activator. Arthritis Rheum 1986; 29: 1397-1401.

23 Bunning R A D, Crawford A, Richardson H J, Opdenakker G, Van Damme J, Russell R G G. Interleukin 1 preferentially stimulates the production of tissue-type plasminogen activator by human articular chondrocytes. Biochem Biophys Acta 1987; 924: 473-82.

24 Saksela O, Hovi T, Vaheri A. Urokinase-type plasminogen activator and its inhibitor secreted by cultured human monocyte-macrophages. F Cell Physiol 1985; 122: 125-32.

25 Vassalli J D, Dayer J M, Wohlwend A, Belin D. Concomitant secretion of prourokinase and of a plasminogen activatorspecific inhibitor by cultured human monocyte-macrophages. F Exp Med 1984; 159: 1653-68.

26 Van Hinsberg V W M, Van den Berg E A, Fiers W, Dooijewaard $G$. Tumor necrosis factor induces the production of urokinase-type plasminogen activator by human endothelial cells. Blood 1990; 75: 1991-8.

27 Gurewich V. The sequential, complementary and synergistic activation of fibrin-bound plasminogen by tissue plasminogen activator and pro-urokinase. Fibrinolysis 1989; 3: minoge.

28 Brommer E J P, Boks A L, Koopman J, Haverkate F. Protraction of whole blood and plasma clot lysis in patients with high levels of an inhibitor of tissue-type plasminogen activator. Thromb Res 1985; 39: 271-80.

29 Knabb R M, Chiu A T, Reilly T M. Effects of recombinant plasminogen activator inhibitor type 1 on fibrinolysis in vitro and in vivo. Thromb Res 1990; 59: 309-17.

30 Van Hinsbergh V W M, Kooistra T, Scheffer M A, Van Bockel J H, Van Muijen G N P. Characterization and fibrinolytic properties of human omental tissue mesothelial cells. Comparison with endothelial cells. Blood 1990; 75: $1490-7$

31 Mizel S B, Dayer J M, Krane S M, Mergenhagen S E. Stimulation of rheumatoid synovial cell collagenase and prostaglandin production by partially purified lymphocyteprostaglandin production by partially purified lymphocyteactivating factor (int

32 Firestein G R, Xu W D, Townsend K, Glasebrock A, Broide D H, Zwaifler N. Cytokine profile in rheumatoid arthritis suggests a localized autologous mixed lymphocyte reaction. Arthritis Rheum 1988; 31: R16.

33 Staite N D, Richard K H, Aspar D G, Franz K A, Galinet L A, Dunn C J. Induction of actue erosive monoarticular arthritis in mice by interleukin 1 and methylated bovine arthritis in mice by interleukin 1 and methylated

34 Philippé J, Offner F, Declerck P J, et al. Fibrinolysis and coagulation in patients with infectious diseases and sepsis. Thromb Haemost 1991; 65: 291-5.

35 Butler M, Colombo C, Hickman L, et al. A model of osteoarthritis in rabbits. Evaluation of antiosteoarthritic effects of intraarticularly administered drugs. Arthritis Rheum 1983; 26: 1380-6.

36 Matsuo O, Tanaka S, Kikuchi H. Effect of urinary trypsin inhibitor on osteoarthritis. Thromb Res 1988; 52: $237-45$. 